ORIGINAL ARTICLE

\title{
Identification of helicobacter species in human liver samples from patients with primary hepatocellular carcinoma
}

\author{
Y Huang, X-G Fan, Z-M Wang, J-H Zhou, X-F Tian, N Li
}

J Clin Pathol 2004;57:1273-1277. doi: 10.1136/jcp.2004.018556

See end of article for authors' affiliations

....................

Correspondence to: Professor X G Fan, Department of Infectious Diseases, Xiangya Hospital, Central South University, Changsha 410008, Hunan, PR China; xgfan@hotmail. com

Accepted for publication 1 June 2004

\begin{abstract}
Aims: Several studies have shown the presence of helicobacter species in the human biliary tract and in the intestinal tract of animals. Experimental infection by Helicobacter hepaticus in mice causes chronic hepatitis and hepatocellular carcinoma (HCC). This study investigated whether helicobacter species could be detected in the liver of patients with HCC.

Methods: Liver samples from 20 patients with primary liver carcinoma diagnosed by histopathology and 16 controls without primary liver carcinoma were studied. Histology with standard and immunohistochemical stains, culture, and polymerase chain reaction (PCR) amplification using helicobacter genus specific 16S rRNA primers were used to detect the presence of bacteria. Amplified products were identified by Southern hybridisation and sequencing. A search for other genes specific for Helicobacter pylori was also performed.

Results: Helicobacter species 16S rDNA was found in eight of 20 samples of primary liver carcinoma, whereas none of the controls harboured this rDNA. Six helicobacter specific PCR amplicons were sequenced and were found to have 98.5-99.0\% similarity to the 16S rDNA of $H$ pylori. Of the eight positive samples, seven were positive in PCR using $26 \mathrm{kDa}$ protein primers and six showed morphological and immunohistochemical evidence of $H$ pylori. The cagA and $g \operatorname{lmM}$ genes were detected in only two samples. The vacA and rps 4 genes were not detected.

Conclusions: Helicobacter can be present in the liver of patients with primary liver carcinoma and is probably linked to the carcinogenic process in the liver.
\end{abstract}

D uring the past few years, helicobacter infections have been reported to be associated with certain liver diseases of some animal species, such as Helicobacter canis in dogs, $H$ pullorum in poultry, and $H$ hepaticus and $H$ bilis in mice. Notably, $H$ hepaticus infection has been found to increase the risk of hepatic carcinoma, particularly in inbred strains of mice. ${ }^{1}$ The human gastric pathogen $H$ pylori induces a persistent infection and is thought to be a type I carcinogen because of its role in the development of gastric carcinoma and gastric mucosa associated lymphoid tissue lymphoma. ${ }^{2}$ It has been proposed that in humans, as in animals, helicobacter species may also colonise the liver and induce chronic hepatic diseases, especially hepatocellular carcinoma (HCC).

HCC is one of the most common human cancers. It results in between 25000 and one million deaths annually. The incidence of HCC varies widely according to geographical location and among ethnic groups. ${ }^{3}$ Those regions where the risk for HCC is high are sub-Saharan Africa, China, and Southeast Asia. Of the newly reported cases of HCC in the world each year, $45 \%$ are found among individuals in mainland China, and HCC is the second leading cause of death as a result of cancer in China.

"It has been proposed that in humans, as in animals, helicobacter species may also colonise the liver and induce chronic hepatic diseases, especially hepatocellular carcinoma"

Several important risk factors for the development of HCC have been identified, including hepatitis B virus (HBV) and hepatitis C virus (HCV) infection, environmental toxins, hereditary haemochromatosis, and cirrhosis of almost any cause. However, HCC also occurs in a considerable proportion of patients without recognised risk factors. It is possible that helicobacter organisms are also a risk factor for HCC. In our previous study, we detected a $400 \mathrm{bp}$ fragment of the $16 \mathrm{~S}$ rRNA gene of helicobacter species in the liver tissue of patients with HCC. Sequence analysis and comparison showed that these helicobacter species were closely related to $H$ pylori ${ }^{4}$ To ascertain whether these helicobacter species were $H$ pylori, in our present study we amplified and sequenced a $1200 \mathrm{bp}$ fragment of the 16S rRNA gene, and searched for other genes that are specific for $H$ pylori by polymerase chain reaction (PCR).

\section{MATERIALS AND METHODS Patients}

Liver tissue samples were collected from 36 patients who underwent hepatic surgery or cholecystectomy. Clinical and pathological data were recorded from each patient's file. Of these 36 patients, 20 (group I: 18 men and two women; mean age, 42 years) had HCC. The other 16 (group II: 10 men and six women; mean age, 36 years) patients, who did not have a malignancy, were considered to be control subjects. Six of these 16 control patients had cholelithiasis, six had hepatic haemangioma, two had a hepatic cyst, and the remaining two had cholecystitis. Informed written consent was obtained from each patient. Table 1 shows the clinical and pathological data of each patient.

\section{Tissue sampling and processing}

Surgically collected liver specimens were fixed in $10 \%$ buffered formalin, embedded in paraffin wax, and stained with haematoxylin and eosin. We also investigated the presence of $H$ pylori by using immunohistochemical staining to detect $H$ pylori. The antibody was diluted $1 / 10$ according

Abbreviations: $\mathrm{HBV}$, hepatitis $B$ virus; $\mathrm{HCC}$, hepatocellular carcinoma; $\mathrm{HCV}$, hepatitis $C$ virus; $P C R$, polymerase chain reaction 
Table 1 Characteristics of patients with (group I) and without (group II) primary liver carcinoma and helicobacter PCR results

\begin{tabular}{|c|c|c|c|c|c|c|c|c|c|c|c|}
\hline \multirow[b]{2}{*}{ Patient } & \multirow[b]{2}{*}{ Sex } & \multirow{2}{*}{$\begin{array}{l}\text { Age } \\
\text { (years) }\end{array}$} & \multirow[b]{2}{*}{ Liver pathology } & \multicolumn{2}{|l|}{ Serological markers } & \multicolumn{6}{|c|}{ Helicobacter PCR results } \\
\hline & & & & HBV-M & Anti-HCV & 16S rRNA & $26 \mathrm{kDa}$ & cag $A$ & vacA & glmM & rps4 \\
\hline \multicolumn{12}{|c|}{ Group 1} \\
\hline 1 & M & 32 & $\mathrm{HCC}$ and mild fibrosis & $\mathrm{HBsAg}+, \mathrm{HBcAb}+$ & - & + & + & + & - & + & - \\
\hline 2 & M & 41 & $\mathrm{HCC}$ and cirrhosis & $\mathrm{HBsAb}+, \mathrm{HBeAb}+, \mathrm{HBcAb}+$ & - & - & - & - & - & - & - \\
\hline 3 & M & 34 & $\mathrm{HCC}$ and mild fibrosis & $\mathrm{HBsAb}+, \mathrm{HBeAb}+, \mathrm{HBcAb}+$ & - & + & + & - & - & - & - \\
\hline 4 & M & 35 & $\mathrm{HCC}$ & $\mathrm{HBsAb}+$ & - & + & + & + & - & - & - \\
\hline 5 & M & 38 & $\mathrm{HCC}$ and cirrhosis & $\mathrm{HBsAb}+, \mathrm{HBeAg}+, \mathrm{HBcAb}+$ & - & - & - & - & - & - & - \\
\hline 6 & M & 29 & $\mathrm{HCC}$ & $\mathrm{HBsAg}+, \mathrm{HBcAb}+$ & - & - & - & - & - & - & - \\
\hline 7 & M & 55 & $\mathrm{HCC}$ and cirrhosis & $\mathrm{HBsAb}+, \mathrm{HBeAb}+, \mathrm{HB} c \mathrm{Ab}+$ & - & + & + & - & - & - & - \\
\hline 8 & $\mathrm{~F}$ & 58 & $\mathrm{HCC}$ and cirrhosis & $\mathrm{HBsAg}+, \mathrm{HBcAb}+$ & - & - & - & - & - & - & - \\
\hline 9 & M & 54 & $\mathrm{HCC}$ and cirrhosis & $\mathrm{HBsAb}+, \mathrm{HBeAb}+, \mathrm{HB} c \mathrm{Ab}+$ & - & - & - & - & - & - & - \\
\hline 10 & M & 64 & $\mathrm{HCC}$ and cirrhosis & $\mathrm{HBsAg}+, \mathrm{HBcAb}+$ & - & + & + & - & - & - & - \\
\hline 11 & M & 37 & $\mathrm{HCC}$ and mild fibrosis & $\mathrm{HBsAg}+, \mathrm{HBcAb}+$ & - & + & + & - & - & - & - \\
\hline 12 & M & 35 & HCC and cirrhosis & $\mathrm{HBsAb}+, \mathrm{HBeAg}+, \mathrm{HBcAb}+$ & - & - & - & - & - & - & - \\
\hline 13 & M & 36 & $\mathrm{HCC}$ and mild fibrosis & $\mathrm{HBsAg}+, \mathrm{HBcAb}+$ & - & - & - & - & - & - & - \\
\hline 14 & M & 42 & HCC and cirrhosis & $\mathrm{HBsAb}+, \mathrm{HBeAg}+, \mathrm{HBcAb}+$ & - & - & - & - & - & - & - \\
\hline 15 & $\mathrm{~F}$ & 60 & HCC and cirrhosis & $\mathrm{HBsAb}+, \mathrm{HBeAg}+, \mathrm{HBcAb}+$ & - & - & - & - & - & - & - \\
\hline 16 & M & 37 & $\mathrm{HCC}$ and mild fibrosis & $\mathrm{HBsAg}+, \mathrm{HBcAb}+$ & - & + & + & - & - & + & - \\
\hline 17 & M & 58 & HCC and cirrhosis & $\mathrm{HBsAg}+, \mathrm{HBcAb}+$ & - & - & - & - & - & - & - \\
\hline 18 & M & 34 & $\mathrm{HCC}$ and mild fibrosis & $\mathrm{HBsAb}+, \mathrm{HBeAg}+, \mathrm{HBcAb}+$ & - & - & - & - & - & - & - \\
\hline 19 & M & 35 & $\mathrm{HCC}$ & $\mathrm{HBs} \mathrm{Ab}+$ & - & + & - & - & - & - & - \\
\hline 20 & M & 32 & $\mathrm{HCC}$ & $\mathrm{HBsAb}+$ & - & - & - & - & - & - & - \\
\hline \multicolumn{12}{|c|}{ Group II } \\
\hline 1 & M & 38 & Cholelithiasis & - & - & - & - & - & - & - & - \\
\hline 2 & $\mathrm{~F}$ & 28 & Haemangioma & - & ND & - & - & - & - & - & - \\
\hline 3 & M & 41 & Cholelithiasis & - & - & - & - & - & - & - & - \\
\hline 4 & M & 39 & Cholelithiasis & - & - & - & - & - & - & - & - \\
\hline 5 & M & 25 & Haemangioma & - & - & - & - & - & - & - & - \\
\hline 6 & M & 34 & Cholelithiasis & - & - & - & - & - & - & - & - \\
\hline 7 & $\mathrm{~F}$ & 54 & Haemangioma & - & - & - & - & - & - & - & - \\
\hline 8 & $\mathrm{~F}$ & 45 & Cholelithiasis & - & ND & - & - & - & - & - & - \\
\hline 9 & M & 36 & Haemangioma & - & - & - & - & - & - & - & - \\
\hline 10 & $\mathrm{~F}$ & 26 & Hepatic cyst & - & - & - & - & - & - & - & - \\
\hline 11 & M & 45 & Haemangioma & - & - & - & - & - & - & - & - \\
\hline 12 & M & 34 & Hepatic cyst & - & ND & - & - & - & - & - & - \\
\hline 13 & M & 29 & Cholelithiasis & - & - & - & - & - & - & - & - \\
\hline 14 & $\mathrm{~F}$ & 32 & Haemangioma & - & - & - & - & - & - & - & - \\
\hline 15 & $\mathrm{~F}$ & 47 & Cholelithiasis & - & - & - & - & - & - & - & - \\
\hline 16 & M & 27 & Cholelithiasis & - & - & - & - & - & - & - & - \\
\hline
\end{tabular}

to the manufacturer's instruction (Dako, Carpenteria, California, USA).

\section{Helicobacter culture}

Fresh tissue specimens from the malignant livers, the peritumorous malignant livers, and the non-tumorous livers were immediately stored at $-4^{\circ} \mathrm{C}$ and transferred to the laboratory. The liver tissue samples were ground and seeded on non-selective media and incubated under microaerobic and anaerobic conditions at $37^{\circ} \mathrm{C}$ for 10 days. Selective antibiotic medium for $\mathrm{H}$ pylori was also used. ${ }^{5}$

\section{DNA extraction}

DNA was extracted from hepatic tissue using a fast method as follows. Liver tissue $(50 \mathrm{mg})$ was homogenised to uniformity and centrifuged at $8000 \times g$ for 10 minutes. The pellet obtained was resuspended in $300 \mu$ l extraction buffer (50mM Tris/HCl, pH 8.3, ImM EDTA, 0.75\% Tween 20) containing $0.3 \mathrm{mg} / \mathrm{ml}$ proteinase $\mathrm{K}$ (AMRESCO, Changsha, China). The samples were incubated at $55^{\circ} \mathrm{C}$ for 12 hours, and proteinase $\mathrm{K}$ was inactivated by boiling for 10 minutes. The remaining cellular debris was sedimented at $10000 \times g$ for 10 minutes. The upper phase, containing the DNA, was stored at $-20^{\circ} \mathrm{C}$ until use as template in the PCR.

\section{PCR amplification}

Samples were amplified by helicobacter genus specific 16S rRNA primers. The forward (C97) and the reverse (C05) primers amplified a product of approximately $1200 \mathrm{bp} .^{6}$ Samples generating a positive result in helicobacter genus PCR were subsequently analysed with five different sets of primers. A primer pair based on the partial DNA sequence of a species specific gene encoding a $26 \mathrm{kDa}$ cell surface protein of $H$ pylori amplified a 298 bp product. ${ }^{7}$ The other four specific primers were used to look for the vacA, ${ }^{8}$ cagA, ${ }^{9}$ and $\operatorname{glmM}^{10}$ genes, which encode potential virulence factors in $\mathrm{H}$ pylori, in addition to the rps4 gene, which encodes the $H$ pylori ribosomal protein S4. Table 2 shows the nucleotide sequences of the primers used, the PCR conditions, and the size of the amplified fragments. The amplified products were analysed on a $1.5 \%(\mathrm{wt} / \mathrm{vol})$ agarose gel, which was stained with ethidium bromide and observed under short wavelength ultraviolet light.

\section{Southern blot analysis}

To confirm which amplicons were of bacterial 16S rRNA origin, rather than non-specific human genomic origin, Southern blot analysis was performed with a 16S rDNA helicobacter probe generated by amplification of $H$ pylori strain ATCC (American Type Culture Collection) 49503 with C97/C98 primers. ${ }^{6}$ The probe was labelled with ${ }^{32} \mathrm{P}$-dCTP molecules according to the manufacturer's instruction (Promega, Madison, Wisconsin, USA). Aliquots $(10 \mu \mathrm{l})$ of the PCR product were electrophoresed through a $1 \%$ agarose gel and transferred on to a nylon membrane (Boehringer Mannheim, Mannheim, Germany) by the capillary blotting 
Table 2 Oligonucleotide primers used to amplify the 16S rRNA and Helicobacter pylori specific genes

\begin{tabular}{|c|c|c|c|c|}
\hline Gene & Sequence $\left(5^{\prime}\right.$ to $\left.3^{\prime}\right)$ & Reaction conditions & Amplicon size (bp) & Position \\
\hline $16 \mathrm{~S}$ rRNA & $\begin{array}{l}\text { GTCATGACGGGTATCC } \\
\text { ACTTCACCCCAGTCGCTG }\end{array}$ & $\begin{array}{l}94^{\circ} \mathrm{C} \text { for } 1 \mathrm{~min}, 55^{\circ} \mathrm{C} \text { for } 2 \mathrm{~min}, 72^{\circ} \mathrm{C} \\
\text { for } 2.5 \mathrm{~min}(35 \text { cycles) } \\
98^{\circ} \mathrm{C} \text { for } 10 \text { min }(1 \text { cycle) }\end{array}$ & $1200 \mathrm{bp}$ & $\begin{array}{l}276-291 \\
1495-1478\end{array}$ \\
\hline $26 \mathrm{kDa}$ & $\begin{array}{l}\text { TGGCGTGTCTATTGACAGCGAGC } \\
\text { CCTGCTGGGCATACTTCACCATG }\end{array}$ & $\begin{array}{l}94^{\circ} \mathrm{C} \text { for } 30 \mathrm{sec}, 68^{\circ} \mathrm{C} \text { for } 1 \mathrm{~min}(37 \mathrm{cycles}) \\
94^{\circ} \mathrm{C} \text { for } 30 \mathrm{sec}, 68^{\circ} \mathrm{C} \text { for } 1 \mathrm{~min}, 72^{\circ} \mathrm{C} \text { for } \\
2 \mathrm{~min}(6 \text { cycles) }\end{array}$ & $298 \mathrm{bp}$ & $\begin{array}{l}474-496 \\
776-754\end{array}$ \\
\hline $\operatorname{cag} \mathrm{A}$ & $\begin{array}{l}\text { ATAATGCTAAATTAGACAACTTGAGCGA } \\
\text { TTAGAATAATCAACAAACATCACGCCAT }\end{array}$ & $\begin{array}{l}94^{\circ} \mathrm{C} \text { for } 1 \mathrm{~min}, 55^{\circ} \mathrm{C} \text { for } 1 \mathrm{~min}, 72^{\circ} \mathrm{C} \text { for } \\
1.5 \mathrm{~min}(35 \text { cycles })\end{array}$ & $297 \mathrm{bp}$ & $\begin{array}{l}1751-1778 \\
2048-2021\end{array}$ \\
\hline glmM & $\begin{array}{l}\text { GGATAAGCTTTAAGGGGTGTIAGGGG } \\
\text { GCTTACTTTCTAACACTAACGCGC }\end{array}$ & $\begin{array}{l}94^{\circ} \mathrm{C} \text { for } 1 \mathrm{~min}, 56^{\circ} \mathrm{C} \text { for } 1 \mathrm{~min}, 72^{\circ} \mathrm{C} \text { for } \\
1 \mathrm{~min}(35 \text { cycles) }\end{array}$ & $296 \mathrm{bp}$ & $\begin{array}{l}1289-1314 \\
1584-1561\end{array}$ \\
\hline $\operatorname{vacA}$ & $\begin{array}{l}\text { GGAGCCCCAGGAAACATTG } \\
\text { CATAACTAGCGCCTTGCAC }\end{array}$ & $\begin{array}{l}94^{\circ} \mathrm{C} \text { for } 1 \mathrm{~min}, 52^{\circ} \mathrm{C} \text { for } 1 \mathrm{~min}, 72^{\circ} \mathrm{C} \text { for } \\
1 \mathrm{~min}(35 \text { cycles) }\end{array}$ & $352 \mathrm{bp}$ & $\begin{array}{l}976-994 \\
1327-1309\end{array}$ \\
\hline rps 4 & $\begin{array}{l}\text { ATGAGTCTTTCTTCATATGGGA } \\
\text { ATGGCAAGATATAGAGGTGCAG }\end{array}$ & $\begin{array}{l}94^{\circ} \mathrm{C} \text { for } 1 \text { min, } 58^{\circ} \mathrm{C} \text { for } 1 \mathrm{~min}, 72^{\circ} \mathrm{C} \text { for } \\
1 \text { min }(40 \text { cycles })\end{array}$ & $605 \mathrm{bp}$ & $\begin{array}{l}605-584 \\
1-22\end{array}$ \\
\hline
\end{tabular}

technique. The membrane was prehybridised at $68^{\circ} \mathrm{C}$ for two hours, freshly denatured probe was added, and hybridisation was performed at $68^{\circ} \mathrm{C}$ overnight.

\section{Sequencing and sequence analysis}

All the amplicons were purified from agarose gel by agarose gel DNA extraction kit (Roche, Indianapolis, Indiana, USA). Sequence analysis was performed with an Applied Biosystems DNA sequencer using primers C05 and C97. Sequence comparison was carried out using the Blast program and the GenBank databases.

\section{RESULTS}

\section{Culture and histopathology}

No bacterial growth was detected from cultures of hepatic tissue under anaerobic or microaerobic conditions, despite a prolonged incubation time. Of 20 specimens in group I, all were diagnosed as HCC pathologically, and the tumours measured $3-12 \mathrm{~cm}$ in diameter. Ten were associated with cirrhosis, whereas the others showed no fibrosis $(\mathrm{n}=6)$ or only mild fibrosis $(\mathrm{n}=4)$ in the underlying liver. All patients had classic HCC, consisting of well to poorly differentiated, malignant hepatocytes arranged in a trabecular or trabeculoglandular pattern with a sinusoidal, vascular network.

\section{Immunohistochemical staining}

Slender, curved microorganisms were detected in the hepatic sinus or portal zone in six of the 20 patients with HCC by specific $H$ pylori immunostaining, whereas no bacteria were found in the control group (fig 1).

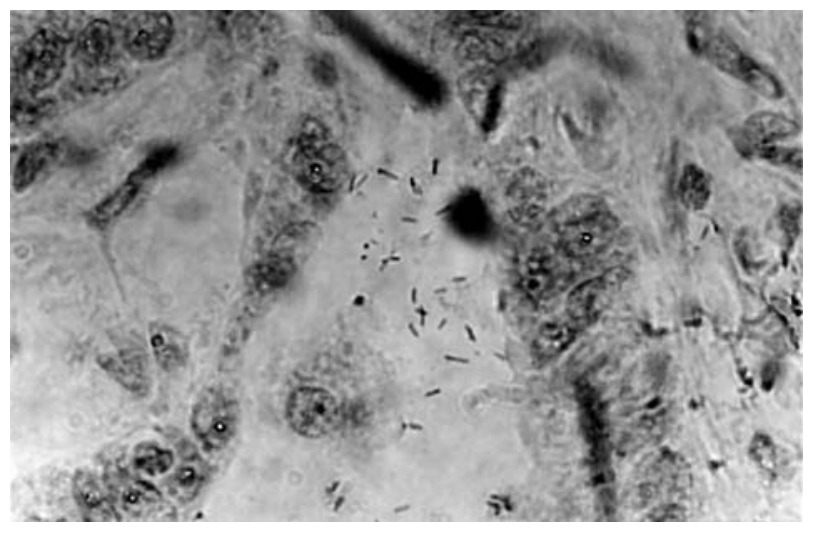

Figure 1 Immunostaining for Helicobacter pylori. Original magnification, $\times 1000$.

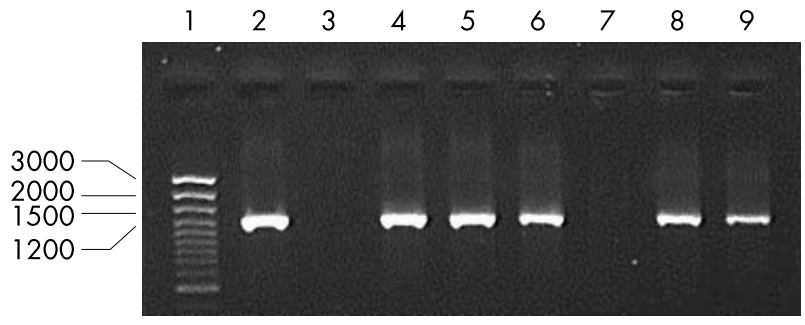

Figure 2 Polymerase chain reaction products of the 1200 bp fragments obtained by helicobacter gene specific amplification. Lane 1, DNA marker; lane 2, positive control (Helicobacter pylori strain ATCC49503); lane 3, negative control; lanes $4-6,8-9$, positive samples from patients with hepatocellular carcinoma; lane 7, negative sample from patient without hepatocellular carcinoma.

\section{PCR amplification with 165 rDNA primers and Southern blot analysis}

Helicobacter genus specific 16S rRNA primers identified helicobacter in eight of 20 samples from the HCC patient group, whereas none of 16 liver samples from patients without HCC were found to have a positive PCR result using the same primers. Under ultraviolet illumination the size of the PCR product corresponded to the expected 1200 bp (fig 2; table 3). Each of the eight amplicons were also found to be positive by Southern blot hybridisation with the ${ }^{32} \mathrm{P}$-dCTP labelled probe generated by PCR using the C97/C98 primers, confirming the presence of a gene sequence of helicobacter in liver tissue samples obtained form patients with HCC. Figure 3 shows the results of Southern blot hybridisation.

DNA sequencing of Helicobacter 16S rRNA amplicons Eight amplicons were fully sequenced to verify that they were truly from the helicobacter 16S rRNA gene and to determine their species identity. All were found to be at least $98.5 \%$ similar to the 16S rRNA gene of $H$ pylori (GenBank accession number AF302106, Z25752) (table 3).

\section{Helicobacter pylori specific gene detection}

Using PCR amplification, a $26 \mathrm{kDa}$ gene was detected in seven of eight samples positive for the helicobacter 16S rRNA gene. The cagA and glmM genes were detectable in only two samples, whereas the vacA and rps4 genes were not detected (table 1).

\section{DISCUSSION}

Recently, several separate research groups have detected helicobacter organisms such as $H$ pylori, $H$ pullorum, $H$ bilis, and $H$ flexispira in the bile, gall bladder, or liver tissue of 
$\begin{array}{lllllllll}1 & 2 & 3 & 4 & 5 & 6 & 7 & 8 & 9\end{array}$

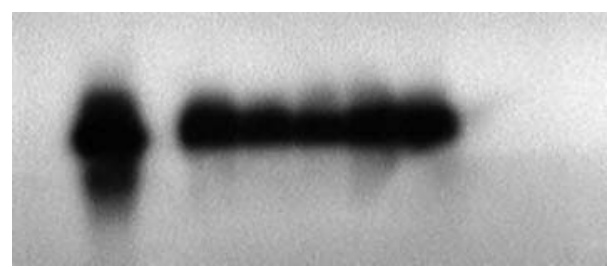

Figure 3 Southern blot hybridisation of a 1200 bp polymerase chain reaction product of genus specific helicobacter positive liver samples and control tissues. Lane 1, positive control (Helicobacter pylori strain ATCC49503); lane 2, negative control; lanes 3-7, positive samples from patients with hepatocellular carcinoma; lanes 8 and 9, negative samples from patients without hepatocellular carcinoma.

patients with primary sclerosing cholangitis, primary biliary cirrhosis, and primary liver carcinoma. ${ }^{11}{ }^{12}$ Another study using PCR and immunohistochemical staining detected a $H$ pylori-like organism in the gallbladder mucosa of a 41 year old woman admitted to hospital with fever and upper right quadrant pain. ${ }^{13} \mathrm{~A}$ high prevalence of antibodies to $\mathrm{H}$ pylori in the serum of patients with liver diseases has also been reported. ${ }^{14}{ }^{15}$ These observations suggested that helicobacter organisms, including $H$ pylori, might play a role in the development of hepatobiliary diseases in humans, as they do in animals.

In our study, helicobacter DNA was detected using $16 \mathrm{~S}$ rDNA specific primers in eight of 20 liver specimens from patients with HCC, compared with none in the control group. When DNA sequences were compared, all were $>98.5 \%$ similar to the $16 \mathrm{~S}$ rRNA gene of $H$ pylori, suggesting a close association with this species. The microorganism was also visualised in the liver tissue by means of specific immunostaining in six of these eight cases. To provide more information on the bacterial species possibly involved in the process, genes specific for $H$ pylori were sought using PCR. The $26 \mathrm{kDa}$ species specific antigen gene encoding a surface protein is present in all strains of $H$ pylori. The cagA gene, which is present in approximately $60 \%$ of strains of $H$ pylori, is a component of the cag pathogenicity island, and is found in the most virulent $H$ pylori strains. The vacA gene, which encodes a vacuolating cytotoxin, is present in all strains, but is expressed in only $60 \%$ of them. The glmM gene encodes phosphoglucosamine mutase, which is involved in lipopolysaccharide biosythesis and is found in all $H$ pylori strains. The rps4 gene, encoding the S4 ribosomal protein of $H$ pylori, is well conserved and is considered to be a molecular chronometer, along with the 16S rRNA gene. In our study, the $26 \mathrm{kDa}$ gene was detected in seven of the eight patients positive using the helicobacter 16S rRNA primers, although it was not detected in the other patient. Both the cagA and glmM genes were found in only two patients, and the vacA and rps4 genes were not detected. Although sequencing of the 16S rRNA gene and detection of the $26 \mathrm{kDa}$ gene indicated that the bacteria present in the liver samples of patients with HCC were $H$ pylori, the absence of the other genes suggested that rather than being "typical" H pylori they may be closely related to $H$ pylori in phylogeny but not identical.

\section{"Although more studies are required to clarify the role that helicobacter infection plays in hepatocellular carcinoma (HCC)-innocent bystander, cofactor, or culprit-the findings of our present study provide evidence that helicobacter species are probably novel infectious agents associated with $\mathrm{HCC}^{\prime \prime}$}

There are two potential reasons for the inability to recover these helicobacter strains, namely: (1) the number of bacteria was too small; (2) the bacteria were not in their usual niche. In the case of $H$ hepaticus induced carcinoma, it is not always possible to grow the bacteria, despite their presence.

Helicobacter might have been present in the liver of these patients as a consequence of the tumour process. HCC may cause chronic intrahepatic cholestasis, which favours secondary colonisation with helicobacter. These organisms may be intestinal helicobacter species that first colonise the biliary tract before reaching the liver. It is also possible that helicobacter species may be involved in the genesis of HCC in humans, in a similar way that $H$ hepaticus causes hepatic carcinoma in mice. Many studies would need to be carried out to identify the exact role of helicobacter species in HCC, such as experiments to investigate the cytotoxic effects of helicobacter on liver cell lines, or the influence of Helicobacter on the cell kinetics of the hepatobiliary system. However, successful isolation and characterisation of the organisms in liver should be accomplished to confirm the relation between helicobacter species and HCC. It is also important to establish a proper animal model using the isolated helicobacter. Finally, prospective studies are necessary to assess the potential cofactor role of helicobacter species in the development of primary liver carcinoma in humans, especially in the context of HBV and HCV infection.

To explore the cause of chronic liver disease, including HCC without known risk factors, many studies were performed that focused on looking for new hepatic viruses. Although more studies are required to clarify the role that helicobacter infection plays in HCC-innocent bystander, cofactor, or culprit-the findings of our present study provide evidence that helicobacter species are probably novel infectious agents associated with HCC. China has an enormous population; HBV infection is present in $>10 \%$ of unselected people in China and is the primary risk factor for HCC. ${ }^{16}$ In addition, the prevalence of $H$ pylori infection is $\sim 50 \%$ among individuals in China. ${ }^{14}$ Therefore, the investigation of the pathological role of helicobacter colonisation in the liver tissue of patients with HCC is an important and valuable task. As progress is made in this area, it will increase our understanding of the aetiopathology of HCC. It may eventually be possible to prevent or arrest the disease with antibiotics or vaccination, especially if treatment can be started at a very early stage.

Table 3 Results of PCR for helicobacter species and DNA sequence comparison

\begin{tabular}{lllll}
\hline & \multirow{2}{*}{$\begin{array}{l}\text { PCR positive for } \\
\text { helicobacter species }\end{array}$} & \multicolumn{2}{l}{ 165 rDNA sequence alignment } \\
\cline { 2 - 4 } \cline { 3 - 4 } & 8 & 6 & Strain & Accession no \\
\hline HCC $(n=20)$ & 0 & 625742 AF302106 \\
Not HCC $(n=16)$ & 0 & H pylori & \\
\hline HCC, hepatocellular carcinoma; PCR, polymerase chain reaction. & & & \\
\hline
\end{tabular}




\section{Take home messages}

- Helicobacter species 16S rDNA was found in eight of 20 samples of primary liver carcinoma, but not in controls

- When DNA sequences were compared, all were $>98.5 \%$ similar to the 16S rRNA gene of $H$ pylori, suggesting a close relation with this species

- Molecular analyses of the $26 \mathrm{kDa}$, cagA, glmM, vacA, and rps4 genes indicated that the organisms detected were not typical $H$ pylori but a closely related species

- Thus, helicobacter can be present in the liver of patients with primary liver carcinoma and is probably linked to the carcinogenic process in the liver

\section{Authors' affiliations}

Y Huang, X-G Fan, X-F Tian, N Li, Department of Infectious Diseases, Xiangya Hospital, Central South University, Changsha 410008, Hunan, PR of China

Z-M Wang, Department of Surgery, Xiangya Hospital

J-H Zhou, Department of Pathology, Xiangya Hospital

\section{REFERENCES}

1 Solnick JV, Schaure DB. Emergence of diverse helicobacter species in the pathogenesis of gastric and enterohepatic diseases. Clin Microbiol Rev 2001;14:59-97.
2 Dunn BE, Cohen H, Blaser MJ. Helicobacter pylori. Clin Microbiol Rev 1997; 10:720-41.

3 Kew MC. Epidemiology of hepatocellular carcinoma. Toxicology 2002;181-182:35-8.

4 Fan XG, Peng XN, Huang Y, et al. Helicobacter species ribosomal DNA recovered from the liver tissue of Chinese patients with primary hepatocellular carcinoma. Clin Infect Dis 2002;35:1555-7.

5 Fan XG, Chua A, Li TG, et al. Survival of Helicobacter pylori in milk and tap water. J Gastroenterol Hepatol 1998;13:1096-8.

6 Fox JG, Decohirst FE, Shen ZL, et al. Hepatic helicobacter species identified in bile and gallbladder tissue from Chileans with chronic cholecystitis. Gastroenterology 1998;114:755-63.

7 Lu JJ, Perng CL, Shyu RY, et al. Comparison of five PCR methods for detection of Helicobacter pylori DNA in gastric tissue. J Clin Microbiol 1999;37:772-4.

8 Atherton JC, Cao P, Peek RM, et al. Mosaicism in vacuolating cytotoxin alleles of Helicobacter pylori. J Biol Chem 1995;270:17771-7.

9 Miehlke S, Kibler K, Kim JG, et al. Allelic variation in the cagA gene of Helicobacter pylori obtained from Korea compared to the United States. Am J Gastroenterol 1996;91:1322-5.

10 Kansau I, Raymond J, Bingen E, et al. Genotyping of Helicobacter pylori isolates by sequencing of PCR products and comparison with the RAPD technique. Res Microbiol 1996;147:661-9.

11 Wadstrom T. Helicobacter in extragastric intestinal and liver disease. Acta Gastroenterol Belg 2000;63:393-4.

12 Nilsson HO, Taneera J, Castedal M, et al. Identification of Helicobacter pylori and other helicobacter species by PCR, hybridization, and partial DNA sequencing in human liver samples from patients with primary sclerosing cholangitis or primary biliary cirrhosis. J Clin Microbiol 2000;38:1072-6.

13 Kawaguchi M, Saito T, Ohno H, et al. Bacteria closely resembling Helicobacter pylori detected immunohistologically and genetically in resected gallbladder mucosa. J Gastroenterol 1996;31:294-8.

14 Fan XG, Zou YY, Wu AH, et al. Seroprevalence of Helicobacter pylori infection in patients with hepatitis B. Br J Biomed Sci 1998;55:176-8.

15 Ponzetto A, Pellicano R, Leone N, et al. Helicobacter pylori seroprevalence in cirrhotic patients with hepatitis B virus infection. Neth J Med 2000;56:206-10.

16 Wu M. Clinical advances in primary liver cancer in China. Hepatogastroenterology 2001;48:29-32. 